\title{
Swarthmore International Relations Journal
}

\section{The Paris Climate Agreement - Harbinger of a New Global Order}

Shana Herman,' 19

Swarthmore College, sherman1@swarthmore.edu

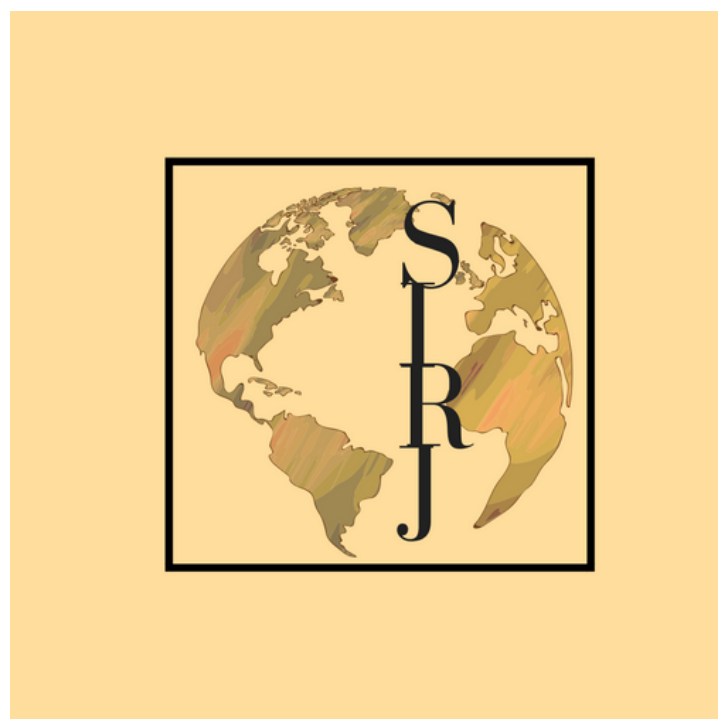

Follow this and additional works at: http://works.swarthmore.edu/swarthmoreirjournal/

\section{Recommended Citation}

Herman, Shana,'19 (2019) "The Paris Climate Agreement - Harbinger of a New Global Order," Swarthmore International Relations Journal at Swarthmore College: Vol. 1: Iss. 3, Article 1. Available at: http://works.swarthmore.edu/swarthmore/vol1/iss3/1

This article is brought to you for free and open access by Works. it has been accepted for inclusion in Swarthmore International Relations Journal at Swarthmore College by an authorized administrator or Works. For more information, please contact myworks@swarthmore

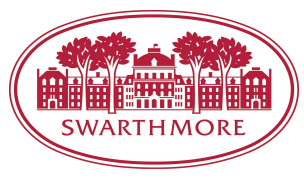




\title{
The Paris Climate Agreement - Harbinger of a New Global Order
}

\author{
Shana Herman \\ Swarthmore College
}

\section{Introduction}

In recent decades, climate change has become an increasingly tangible threat to human existence on Earth. In fact, a combination of climate-related forces (e.g. natural disasters, extreme weather events, and droughts) and carbon-related forces (e.g. air pollution and asthma) already claim about five million lives annually. ${ }^{1}$ This value is only projected to increase and will account for about six million global deaths per year by $2030 .^{2}$ While climate change has and will continue to disproportionately affect low-income communities, people of color, and indigenous populations, as well as poorer and smaller countries and island nations that are the least responsible for the carbon dioxide emissions that have contributed to it, climate change is indisputably a collective global crisis with shared consequences that will ultimately affect every country on Earth, regardless of affluence or military prowess. ${ }^{3}$

Recently, as the consequences of anthropogenic climate change have grown increasingly visible, countries have begun to come together to address this crisis on an international level. In November of 2015, leaders from 197 countries met with the goal of ushering in a new era of international climate change negotiations characterized by meaningful national commitments to mitigate climate change and secure a livable future for all. The product of this conference became known as the Paris Agreement. Since its conception, the Agreement has been praisedby politicians, international relations scholars, nongovernmental organizations (NGOs), and more-as "historic," "a landmark agreement," "a turning point" for our planet and for the international climate regime, and "the world's greatest diplomatic success." 4 The Agreement has also been criticized for being "far too weak" and for providing the world with a sense of "false hope."

\footnotetext{
${ }^{1}$ Climate Vulnerability Monitor: A Guide to the Cold Calculus of a Hot Planet, report, 2nd ed., 15, accessed October 10, 2017, http://daraint.org/wp-content/uploads/2012/09/CVM2-Low.pdf.

2 Ibid, 17.

3 Julian Agyeman, Harriet Bulkeley, and Aditya Nochur, "Climate Justice," in Ignition: What What You Can Do to Fight Global Warming and Spark a Movement, ed. John Isham and S. Waage (Washington D.C.: Island Press, 2007), 136.

4 Daniel Bodansky, “The Paris Climate Change Agreement: A New Hope?” The American Journal of International Law 110, no. 2 (2016): 289, accessed October 10, 2017. doi:10.5305/amerjintelaw.110.2.0288.

5 Tom Bawden, "Paris Climate Deal 'Far Too Weak to Prevent Devastating Global Warming," The Independent, January 8, 2016, http:/www.independent.co.uk/environment/climate-change/cop21-paris-deal-far-too-weak-toprevent-devastating-climate-change-academics-warn-a6803096.html.
} 
This paper investigates how the politics of the Paris Climate Agreement - its design, ratification, and enforcement - both reaffirm and challenge the existing global order. Throughout this paper, "Party," "state," and "country" will be used interchangeably. The design and ratification of the Agreement have facilitated international cooperation by inhibiting free-riding through social pressure and transparency, and by enabling Parties to determine their own mitigation commitments; this in turn supports the existing global order in which states share and exercise power through international institutions. Simultaneously, the enforcement of the Paris Agreement has already begun to meaningfully challenge the existing global order by redistributing power among its actors, evident in the increasing influence of substate and nonstate actors in international politics. Overall, while some aspects of the Agreement's development and function reaffirm the existing global order, the politics of the Paris Agreement provide clear evidence of a new emerging global order. The Paris Agreement therefore has very significant implications for the future of international relations.

\section{Background}

Before delving into how the politics of the Paris Agreement are indicative of a new emerging global order, it is essential to first clarify what is meant by global order. According to scholar Richard Falk, the global order refers to "the distribution of power and authority among the political actors on the global stage." " Power can be defined as "the means by which a state or other actor wields or can assert actual or potential influence or coercion relative to other states and non state actors because of the potential, geographic, economic and financial, technological, military, social, cultural, or other capabilities it possesses."7 Soft power is of particular concern in this paper. In essence, soft power refers to "non-material capabilities such as reputation, culture, and value appeal that can aid the attainment of a state's objectives." 8 As renowned international relations scholar Joseph Nye argues, soft power is not exercised through military or economic force, but rather, it is "the ability to shape the preferences of others" and "[get] others to want outcomes that you want." The exertion of soft power by states is frequently facilitated through international negotiations and institutions. Collaboration through democratic international institutions, such as the United Nations Framework Convention on Climate Change (UNFCCC), is a key norm that characterizes the existing global order that emerged after the end of World War II in 1945 and that is largely defined by liberal international relations theory. ${ }^{10}$

\footnotetext{
${ }^{6}$ Richard Falk, "World Orders, Old and New," Current History 98 (January 1, 1999): 29, accessed January 10, 2018, https://search-proquest-com.proxy.swarthmore.edu/docview/1309780844?pq-origsite=gscholar.

${ }^{7}$ Paul R. Viotti and Mark V. Kauppi, International Relations and World Politics, 5th ed. (New York, NY: Pearson, 2013), 202.

8 Ibid, 207.

9 Joseph S. Nye, Jr., Soft Power: The Means to Success in World Politics (New York: PublicAffairs, 2005$), 5$.

10 Joseph S. Nye, Jr., "Will the Liberal Order Survive?" Foreign Affairs 96, no. 1 (Jan. \& Feb. 2017):, accessed January 7, 2018, https://www.foreignaffairs.com/articles/2016-12-12/will-liberal-order-survive.
} 
Another key element of the existing global order is that, for decades, states (i.e. national governments) have been the primary actors in the international arena.

As previously mentioned, the Paris Agreement was the culminating product of the twenty-first Conference of the Parties to the UNFCCC (COP 21), held in Paris in November of 2015. Of the 197 Parties that attended the Convention, 179 have ratified the Agreement to date. ${ }^{11}$ While it is projected that more Parties will soon ratify the Agreement, many of those that appear to be hesitant are oil-rich countries that are heavily dependent on the petroleum industry. ${ }^{12}$ The Paris Agreement has three key goals: first, to keep average global temperatures well below 2 degrees Celsius of warming above pre-industrial levels, and strive to limit this increase to 1.5 degrees Celsius above pre-industrial levels; next, to increase adaptation and resilience mechanisms and development of technologies to reduce greenhouse gas emissions without compromising food production; and finally, to allocate funds appropriately and efficiently in order to achieve the previously stated goals. ${ }^{13}$

The Paris Agreement differs from previous international climate negotiations, which have generally employed top-down command-and-control strategies involving legally binding obligations, in that it does not prescribe or mandate minimum emission reduction targets; rather, the Paris Agreement provides Parties with the flexibility to establish their own intended nationally determined commitments (INDCs or NDCs) to reduce emissions in a bottom-up approach. ${ }^{14}$ These NDCs are intended to go into effect in 2020, with the goal of countries peaking their emissions as soon as possible. ${ }^{15}$

While the Paris Agreement does not require that Parties meet specific emission reduction targets or reduce their emissions through any particular mechanisms, it does require each Party to "prepare, communicate, and maintain successive [NDCs]", and "pursue domestic mitigation measures" to achieve the goals of these contributions. ${ }^{16}$ In essence, Parties are solely required to publish reports detailing their goals and progress. The agreement also contains a "ratchet mechanism." Parties are required to communicate an NDC every five years, with the assumption that states will steadily increase the ambition of these commitments over time, ultimately achieving net zero emissions by the second half of the century. ${ }^{17}$ Through these NDCs, the Agreement introduces the concept of common but differentiated responsibilities and respective

\footnotetext{
11 “The Paris Agreement - Status of Ratification," UNFCCC, accessed July 26, 2018, https://unfccc.int/process/theparis-agreement/status-of-ratification.

12 "Paris Agreement Ratification Tracker," Climate Analytics, accessed January 14, 2018 , http://climateanalytics.org/briefings/ratification-tracker.html.

13 "Paris Agreement," UNFCCC, 2, accessed July 26, 2018, https://unfccc.int/files/meetings/paris_nov_2015/application/pdf/paris_agreement_english_.pdf.

14 Jennifer Jacquet and Dale Jamieson, "Soft but significant power in the Paris Agreement," Nature Climate Change 6, no. 7 (July 2016): 644, accessed October 10, 2017, doi:10.1038/nclimate3006.

15 "Paris Agreement," 3.

16 Ibid.

17 Sophie Yeo, “Timeline: The Paris Agreement's 'Ratchet Mechanism,"” Carbon Brief, January 19, 2016, https://www.carbonbrief.org/timeline-the-paris-agreements-ratchet-mechanism.
} 
capabilities of different countries to address climate change, depending on distinct national circumstances; this approach is designed to increase equity in mitigation burden. ${ }^{18}$

\section{The Politics of Design \& Ratification - Facilitating International Cooperation}

Despite the potential for increased equity to promote cooperation between countries, many realist international relations scholars argue that there exist significant barriers to cooperation. One of the core tenets of realism is that states are self-interested actors that are constantly engaged with other states in a perpetual struggle for power. ${ }^{19}$ Many realists attribute this struggle to states' inherent concern for their own survival. ${ }^{20}$ This mentality of selfpreservation may present an issue in international negotiations. According to realist thinker Kenneth Waltz,

Great tasks can be accomplished only by agents of great capability. That is why states, and especially the major ones, are called on to do what is necessary for the world's survival. But states have to do whatever they think is necessary for their own preservation, since no one can be relied on to do it for them. ${ }^{21}$

Since the Paris Agreement enables Parties to establish their own emission reduction commitments without imposing a minimum target, Waltz's claim implies that, because states are unlikely to place international interests above national interests, Parties may set low commitments so as to avoid jeopardizing national interests, such as economic security. In this way, Parties will benefit from the efforts taken by other states to mitigate climate change without making their own contributions, essentially free-riding. ${ }^{22}$ Realists argue that the Paris Agreement further enables free-riding due to its lack of enforcement and repercussion mechanisms for Parties that do not fulfill their NDCs. ${ }^{23}$ Ultimately, realists believe that the free-riding produced by this Agreement will make international cooperation difficult to sustain.

Renowned realist John Mearsheimer asserts that "states can cooperate, although cooperation is sometimes difficult to achieve and always difficult to sustain. Two factors inhibit

\footnotetext{
18 "Paris Agreement," 2.

19 Stephen M. Walt, “International Relations: One World, Many Theories," Foreign Policy, no. 110 (1998): 31 , doi: $10.2307 / 1149275$.

20 Ibid.

${ }^{21}$ Kenneth Neal Waltz, "The Anarchic Structure of World Politics," in Theory of International Politics (McGraw Hill, 1979), 44, accessed October 10, 2017, http:/www.drmalikcikk.atw.hu/wp_readings/waltz.pdf.

22 Susanne Dröge, "The Paris Agreement 2015: Turning Point for the International Climate Regime," Stiftung Wissenschaft und Politik German Institute for International and Security Affairs, February 2016, 8, accessed October 10, 2017, https://www.swp-berlin.org/fileadmin/contents/products/research_papers/2016RP04_dge.pdf. 23 Guri Bang, Jon Hovi, and Tora Skodvin, "The Paris Agreement: Short-Term and Long-Term Effectiveness," Politics and Governance 4, no. 3 (2016): 211, accessed October 10, 2017, doi:10.17645/pag,y4i3.640.
} 
cooperation: considerations about relative gains and concern about cheating." 24 In the case of the Paris Agreement, Parties worry that by substantially committing to reduce their emissions, they will benefit, but ultimately less than Parties that make smaller commitments, due to the national burdens of reducing emissions. Parties also fear that others will cheat by free-riding on their efforts, rather than establishing their own significant commitments.

Despite the validity of these concerns, the Paris Agreement combats these barriers to cooperation in several ways. Firstly, because other Parties will be reporting commitments and the progress that they have made in attaining these goals, the Paris Agreement fosters a strong culture of international social pressure. ${ }^{25}$ It reflects poorly on a Party if they do not set forth and attempt to uphold meaningful commitments. Failing to take meaningful action to address the climate crisis and free-riding on the efforts of other countries, especially if this behavior comes from wealthier countries that are responsible for the majority of emissions, does not only harm a Party's public image, but also its relations with other Parties. ${ }^{26}$ The influence of social pressure, however, lies not in the Party's public image itself, but rather how that image matches up to those of other Parties. As scholars Ann Towns and Bahar Rumelili argue, "[i]t is through comparative assessments — the normative ordering of states as superior and inferior and placement in a social hierarchy - that social pressure is exerted and states are prodded into action;" social pressure is powerful and effective because states do not want to rank low in this social hierarchy. ${ }^{27}$ Parties, as a result, are likely to set meaningful NDCs and strive to achieve these goals in order to avoid such repercussions. ${ }^{28}$

The Paris Agreement's requirement for transparency through mandatory NDC reporting further pressures Parties to put forward and meet significant commitments. By making information regarding Parties' commitments and progress (or lack thereof) publically available, the Paris Agreement encourages other Parties and the broader public to "name and shame" Parties that are not taking meaningful action to reduce their emissions. ${ }^{29}$ If a Party sets forth a comparatively weak commitment (defying international normative standards) or if its actual behavior does not align with its stated commitments (hypocrisy), exposing and bringing public attention to these gaps "renders the targeted state as a transgressor or underperformer, which

\footnotetext{
24 John J. Mearsheimer, “Anarchy and the Struggle for Power," in The Tragedy of Great Power Politics (New York: W.W. Norton \& Company, 2014), 51-52, accessed October 10, 2017, http://www.ucs.mun.ca/ russellw/Teaching_files/Mearsheimer\%20-\%20Realism.pdf.

25 Bodansky, “The Paris Climate Change Agreement: A New Hope?" 291.

26 Samantha Page, “No, The Paris Climate Agreement Isn't Binding. Here's Why That Doesn't Matter," accessed October 10, 2017, https://thinkprogress.org/no-the-paris-climate-agreement-isnt-binding-here-s-why-that-doesn-tmatter-62827c72bb04/.

27 Ann E. Towns and Bahar Rumelili, "Taking the Pressure: Unpacking the Relation between Norms, Social Hierarchies, and Social Pressures on States," European Journal of International Relations 23, no. 4 (2017): 756, accessed April 25, 2018, doi:10.1177/1354066116682070.

28 Page, "No, The Paris Climate Agreement Isn't Binding. Here's Why That Doesn't Matter."

${ }^{29}$ Catherine Martini, “Transparency: The Backbone of the Paris Agreement,” accessed October 10, 2017, http://envirocenter.yale.edu/transparency-the-backbone-of-the-Paris-Agreement.
} 
produces embarrassment, shame, or status anxiety. ${ }^{, 30}$ Transparency therefore incentivizes Parties to attain their NDCs in an attempt to avoid international public judgement. ${ }^{31}$ The exposure of this gap alone, however, is not sufficient to influence state behavior; here, the concept of social hierarchies and the role that they play in producing social pressure are central. As Towns and Rumelili assert, "[s]tates do not simply respond to the exposure of a gap between a norm or commitment and actual deeds - they react to being compared as inferior or superior to other states by means of norms. [...] [T] he placement of states in a social hierarchy is a key dynamic in social pressure and in the generation of shame. ${ }^{, 32}$ Social pressure to avoid being perceived as inferior to other states therefore epitomizes states' ability to exercise soft power through international institutions.

In Activists Beyond Borders, authors Margaret Keck and Kathryn Sikkink claim that "moral leverage may be especially relevant where states are actively trying to raise their status in the international system" (i.e. move up in the international social hierarchy). ${ }^{33}$ As previously discussed, the realist view of international relations maintains that all states are in a perpetual struggle for power, obtained through positionality in the international system in relation to other states. According to this view, every state is therefore perpetually striving to achieve this goal. If moral leverage, such as that gained by meaningfully committing to reduce emissions and mitigate climate change (especially when other states commit less), does indeed play an important role in raising a state's status in the international system, it is natural to infer that states will set forth and endeavor to attain meaningful commitments. Ultimately, the international social pressure produced by the Paris Agreement's requirements for continual reporting and transparency inhibits free-riding with respect to mitigation efforts and facilitates international cooperation; this in turn reaffirms the existing global order in which states share and exercise power through international institutions because through this social pressure, states are collectively able to exert influence over certain states that may otherwise free-ride.

Beyond combatting issues associated with relative gains and free-riding, the politics of the Paris Agreement also promote cooperation by allowing Parties to determine their own mitigation commitments. Previously, international climate negotiations were centered around legally binding emission reduction targets based on a country's historic emission levels and financial ability. This approach has historically deterred Parties, specifically more industrialized nations, from ratifying international climate negotiations, such as the Kyoto Protocol. ${ }^{34} \mathrm{By}$ altering its strategy and introducing the concept of NDCs, the Paris Agreement eliminates one of

\footnotetext{
${ }^{30}$ Towns and Rumelili, "Taking the Pressure: Unpacking the Relation between Norms, Social Hierarchies, and Social Pressures on States," 757.

31 Bodansky, “The Paris Climate Change Agreement: A New Hope?” 291.

${ }^{32}$ Towns and Rumelili, "Taking the Pressure: Unpacking the Relation between Norms, Social Hierarchies, and Social Pressures on States," 757.

33 Margaret E. Keck and Kathryn Sikkink, Activists beyond Borders (Cornell University Press, 1998$), 29$.

${ }^{34}$ Robert Falkner, "The Paris Agreement and the new logic of international climate politics," International Affairs 92, no. 5 (September 2016): 1108, accessed October 10, 2017, doi:10.1111/1468-2346.12708.
} 
the greatest barriers to international cooperation surrounding climate change mitigation. ${ }^{35}$ Eliminating this barrier to cooperation, however, may introduce a moral hazard problem since the Parties that will sign onto the Paris Agreement due to its non-binding and voluntary approach, but would not sign onto more stringent agreements, are likely the least committed states to developing and implementing comprehensive climate policy. Despite this concern, there is still value in attracting these countries to the Agreement since any contribution to mitigating climate change is better than none. Additionally, as Nye asserts, "attraction leads to acquiescence" through the exercising of soft power (e.g. social pressure). ${ }^{36}$

As previously discussed, social pressure may also influence these states to take meaningful action. Overall, through encouraging cooperation between countries, the design and ratification of the Paris Agreement reaffirm the liberal global order defined by international cooperation and the sharing and exercising of state power through democratic institutions, negotiations, and treaties.

\section{The Politics of Enforcement - Increasing Influence of Substate \& Nonstate Actors}

While some aspects of the Agreement's design and ratification reaffirm the existing global order, the politics surrounding the enforcement of the Paris Agreement are indicative of a new emerging global order. Firstly, the politics of the Paris Agreement redistribute power among the political actors on the global stage by increasing the power and influence of substate and nonstate actors. In recent years across many sectors of society, substate and nonstate actorsincluding civil society, NGOs, social movements, businesses, trade unions, regional and local governments, cities, municipalities, indigenous peoples, and youth - have become increasingly influential in the international political arena. ${ }^{37}$ In the past several decades, substate and nonstate actors have increasingly taken action to address climate change independently, through transnational networks, and in collaboration with states and international organizations; such efforts multiplied greatly and garnered substantial attention in the lead-up to and during the negotiations in Paris. ${ }^{38}$ The politics of the Paris Agreement exemplify the mounting influence of substate and nonstate actors in the international climate regime. In fact, a key element of COP 21 was the regime's embrace of climate action by such actors. ${ }^{39}$

At previous COPs, many substate and nonstate actors have participated as observer organizations. Under this role, they may attend certain intergovernmental negotiations and

\footnotetext{
35 Falkner, "The Paris Agreement and the new logic of international climate politics," 1108.

36 Nye, Soft Power: The Means to Success in World Politics, 6.

${ }^{37}$ Karin Bäckstrand et al., "Non-state actors in global climate governance: from Copenhagen to Paris and beyond," Environmental Politics 26, no. 4 (May 26, 2017): 562, accessed January 7, 2018, doi:10.1080/09644016.2017.1327485.

38 Thomas Hale, "'All Hands on Deck': The Paris Agreement and Nonstate Climate Action," Global Environmental Politics 16, no. 3 (August 2016): 13, accessed January 7, 2018, doi:10.1162/glep_a_00362.

39 Ibid, 12.
} 
occasionally submit information and comments. ${ }^{40}$ The Paris Agreement reaffirms this role, stating that "[a]ny body or agency, whether national or international, governmental or nongovernmental, which is qualified in matters covered by this Agreement and which has informed the secretariat of its wish to be represented at a session of the Conference of the Parties serving as the meeting of the Parties to this Agreement as an observer, may be so admitted unless at least one third of the Parties present object." ${ }^{, 41}$ Many substate and nonstate actors have also organized side events, exhibitions, and protests during the negotiations. ${ }^{42}$ Such actors have historically played the role of activist, lobbyist, and information provider. ${ }^{43}$ While substate and nonstate actors continue to be present at COPs as observer organizations, the design of the Paris Agreement provides such actors with a greater role in monitoring national action and experimenting with local, regional, and transnational approaches to mitigating and adapting to climate change. ${ }^{44}$

The ways in which the Paris Agreement establishes a larger role for substate and nonstate actors, thereby increasing their influence, are evident in the text of the Agreement. ${ }^{45}$ In "[r]ecognizing the importance of the engagements of all levels of government and various actors, in accordance with respective national legislations of Parties, in addressing climate change," the Agreement explicitly seeks to "[e]nhance public and private sector participation in the implementation of nationally determined contributions" and "[t]o incentivize and facilitate participation in the mitigation of greenhouse gas emissions by public and private entities authorized by a Party." ${ }^{46}$ Furthermore, the Agreement requires Parties to "cooperate in taking measures, as appropriate, to enhance climate change education, training, public awareness, public participation and public access to information, recognizing the importance of these steps with respect to enhancing actions under this Agreement." ${ }^{47}$ The Paris Agreement's goal in expanding and strengthening the role of substate and nonstate actors is to assist Parties in implementing NDCs, and to increase public engagement and participation in order to enhance mitigation efforts. To reiterate, power essentially refers to the ability of actors to assert influence relative to other actors. Through explicitly providing substate and nonstate actors with a more significant role in the international climate regime, the Paris Agreement increases the power of

\footnotetext{
${ }^{40}$ Harro van Asselt, "The Role of Non-State Actors in Reviewing Ambition, Implementation, and Compliance Under the Paris Agreement," Climate Law 6, no. 1 (2016): 4, accessed January 7, 2018, doi:10.1163/1878656100601006.

41 "Paris Agreement," 13.

42 Van Asselt, "The Role of Non-State Actors in Reviewing Ambition, Implementation, and Compliance Under the Paris Agreement," 4.

43 Ibid.

44 Bäckstrand et al., "Non-state actors in global climate governance: from Copenhagen to Paris and beyond," 562.

45 Hale, "All Hands on Deck': The Paris Agreement and Nonstate Climate Action," 14.

46 "Paris Agreement," 1, 5.

47 Ibid, 10.
} 
these actors, thereby challenging the existing global order, or distribution of power and authority among the political actors on the global stage.

As evidenced above, the Paris Agreement explicitly incentivizes substate and nonstate actors to make independent contributions and assume more of a leadership role in global climate change mitigation, highlighting the growing importance of these actors in international climate governance. As a result of this newfound influence, climate commitments have already been made by "[o]ver 7,000 cities from more than 99 countries with a combined population of 794 million (11 percent of the global population) and around 32 percent of global GDP," as well as "[c]lose to 5,000 companies from over 88 countries representing over \$38 trillion USD in revenue." 48 Additionally, many of these efforts account for significant emission reductions. In fact, the mitigation potential of only a handful of such initiatives is "in the range of 2.5-4 billion tons of $\mathrm{CO}_{2}$ by 2020, more than India emits in a year, and similar in magnitude to the 4-6 billion tons that UN projects the national pledges adopted in Paris will cut by 2030, a decade later." 49

In the absence of national leadership on climate change, the impact of such contributions is even more profound because of the structure of the Agreement in centering substate and nonstate action. For example, in July of 2017, after President Donald Trump decided to withdraw the United States from the Agreement, "California lawmakers approved an extension of the state's cap-and-trade program. In August, a coalition of nine Northeastern and Mid-Atlantic states - the Regional Greenhouse Gas Initiative-agreed to cut an additional 30 percent of climate-warming pollution from the region's power plants between 2020 and 2030."50 Additionally, the governors of California, New York, and Washington recently created the U.S. Climate Alliance, which now includes 14 states and Puerto Rico. In their 2017 annual report, the Alliance reported that they are on track to achieve a $24-29 \%$ reduction in greenhouse gas emissions below 2005 levels by 2025 based on state and local initiatives. ${ }^{51}$

Beyond the actions taken by substate governments in the United States, the Paris Agreement has also influenced significant action by NGOs, businesses, and other organizations. Signify, major lighting company, is working to become carbon neutral in all of its operations by 2020 "[a]s part of its carbon neutral commitment announced in 2015 at UN Climate Change Conference COP21."52 The company has already taken substantial steps to achieve this goal. For

\footnotetext{
48 Angel Hsu et al., "Assessing the Wider World of Non-State and Sub-National Climate Action," (New Haven: Yale Data Driven Environmental Solutions Group, December 10, 2015), 1, accessed January 7, 2018, https:/campuspress.yale.edu/datadriven/files/2015/12/Assessing-the-Wider-World-of-Non-state-and-Sub-nationalClimate-Action-2d5oghz.pdf.

49 Hale, "All Hands on Deck': The Paris Agreement and Nonstate Climate Action," 13.

50 Georgina Gustin, “14 States: We're on Track to Meet Paris Climate Goals, Despite Trump," InsideClimate News, September 22, 2017, accessed January 14, 2018, https://insideclimatenews.org/news/21092017/states-paris-trumpclimate-change-alliance-leadership-jerry-brown-cuomo-inslee-nrdc-2050.

${ }^{51}$ U.S. Climate Alliance Annual Report: Alliance States Take the Lead, report (2017), 7, accessed January 14, 2018, https://tinyurl.com/y87467rc.

52 "Signify Aims to be Carbon Neutral by 2020," We Are Still In, accessed July 27, 2018, https://www.wearestillin.com/success/signify-aims-be-carbon-neutral-2020.
} 
example, "Signify is purchasing $250,000 \mathrm{MWh}$ of electricity per year over the next 15 years from the Hidalgo Wind Farm in McCook, Texas, to power all of its North American operations with $100 \%$ renewable electricity. This effort reduces carbon footprint by 125,000 metric tons yearly - the equivalent of $\mathrm{CO} 2$ produced by over 26,000 cars in one year., ${ }^{, 53}$ Since the establishment of this carbon neutrality goal is a direct result of the Agreement, Signify's efforts explicitly demonstrate how the Paris Agreement has empowered substate and nonstate actors to take meaningful independent action to address climate change, thereby increasing their influence as a key player in global mitigation efforts.

Since the creation of this Agreement, the Monterey Bay Aquarium has also taken action to combat the global climate crisis. The Aquarium has been working to increase energy efficiency, and was certified as a carbon-neutral organization in $2017 .{ }^{54}$ More recently, "[o]n March 1, 2018, the Aquarium's electricity became 'carbon free' when it enrolled in Monterey Bay Community Power (MBCP), a new community choice aggregator serving Monterey, Santa Cruz and San Benito counties." ${ }^{, 55}$ We Are Still In, a multi-organization NGO created in June 2017 in response to the U.S.'s withdrawal from the Paris Agreement and of which both Signify and the Monterey Bay Aquarium are constituents, explicitly states that the Aquarium has been taking "additional actions to meet or exceed the ambitious emissions targets set by the Paris Agreement as well as the renewable energy and electric vehicle targets set by the State of California. ${ }^{, 56}$ Since the aforementioned initiatives were implemented after the development of the Agreement in 2015, these efforts further illustrate how the Paris Agreement has enabled significant substate and nonstate action, expanding their role in international climate action.

These meaningful contributions, promoted by the Paris Agreement and the politics of its enforcement, exemplify increasing substate and nonstate power because, "[a]s cities, corporations and NGOs have begun to develop their own rules and standards that others chose to follow, they are no longer merely complying with the directives of nation-states or intergovernmental treaties. They have become governors in their own right and established 'private spheres of authority' dislodged from the sovereign state." ${ }^{57}$ By encouraging substate and nonstate actors to adopt independent mitigation measures, and by explicitly providing them with a greater role in the international climate regime, the Paris Agreement and the politics of its enforcement inherently increase these actors' ability to effect change on an international scale; this in turn increases their ability to influence other actors, thereby augmenting their power.

In promoting meaningful involvement in implementing NDCs and ensuring public access to information regarding these commitments, the Paris Agreement also provides substate and

\footnotetext{
53 "Signify Aims to be Carbon Neutral by 2020."

54 "Monterey Bay Aquarium - Inspiring Conservation and Taking Climate Action," We Are Still In, accessed July 27, 2018, https://www.wearestillin.com/success/monterey-bay-aquarium-inspiring-conservation-and-taking-climateaction.

${ }^{55}$ Ibid.

${ }^{56}$ Ibid.

${ }^{57}$ Bäckstrand et al., "Non-state actors in global climate governance: from Copenhagen to Paris and beyond," 568.
} 
nonstate actors with a larger role in monitoring and enforcing state-developed mitigation efforts. The enforcement of the Paris Agreement illustrates climate law and policy scholar Harro van Asselt's argument that substate and nonstate actors are crucial to the monitoring process because such actors are "not subject to the same political constraints as the intergovernmental process, and with the expertise and knowledge of the conditions prevailing in individual states, can thus supplement the formal process by making visible and accessible how much progress is made." The Paris Agreement also empowers these actors to investigate whether action being taken by a national government is fair and ambitious. Such assessments can benefit the state that is under review by providing information regarding how to fill existing gaps and make greater progress in achieving a state's NDC. Additionally, this information can be used by civil society, state and local government officials, and other national and subnational actors to effect change on a smaller scale. In enabling substate and nonstate actors to facilitate transparency by assessing and publicizing progress, fairness, and ambition, the Paris Agreement entrusts these actors with a crucial role in enforcing NDCs and promoting compliance through the mechanisms of social pressure previously detailed. ${ }^{59}$ The enforcement of this Agreement actively encourages substate and nonstate climate action, including monitoring state efforts, in the hope that such action will pressure state actors to put forward ambitious commitments and "ratchet up" these commitments over time. ${ }^{60}$ By increasing the role of substate and nonstate actors in monitoring and enforcing NDCs, the Paris Agreement therefore provides these actors with a greater ability to influence state behavior, consequently shaping international politics and augmenting the power of these actors.

Overall, the text of the Paris Agreement indicates that authority is no longer vested solely in state actors and national governments. As Karin Bäckstrand, Jonathan Kuyper, Björn-Ola Linnér, and Eva Lövbrand argue in their investigation of non-state actors in global climate governance, "[t]he Paris Agreement accepts that NDCs submitted by states are the backbone of mitigation, adaptation, and finance, but also acknowledges that non-state actors are indispensable in these pursuits as governors, implementers, experts and watchdogs."61 In fact, a program, known as the Lima-Paris Action Agenda (LPAA), that was created by the governments of France and Peru, the UNFCCC, and the UN Secretary-General in an attempt to promote substate and nonstate climate action, was declared "a fourth pillar of COP 21 alongside, and equal to, the national pledges, the financing package, and the negotiated agreement."62 This statement further supports that "the Paris Agreement institutionalizes an intricate interplay between state and nonstate, multilateral and transnational climate action," and that "[...] public and private authority is

\footnotetext{
${ }^{58}$ Van Asselt, "The Role of Non-State Actors in Reviewing Ambition, Implementation, and Compliance Under the Paris Agreement," 12.

59 Ibid, 4-5.

${ }^{60}$ Hale, "'All Hands on Deck': The Paris Agreement and Nonstate Climate Action," 13.

${ }^{61}$ Bäckstrand et al., "Non-state actors in global climate governance: from Copenhagen to Paris and beyond," $567-$ 568.

${ }^{62}$ Hale, “'All Hands on Deck': The Paris Agreement and Nonstate Climate Action,” 14.
} 
deeply intertwined in the new landscape of international climate cooperation" arising from the adoption of this Agreement. ${ }^{63}$ Due to the explicitly inclusive and empowering language of the Agreement and the subsequent action that is already being taken by substate and nonstate actors globally, such actors have become central to the international climate regime since COP $21 .{ }^{64}$ As scholar Thomas Hale argues, the explicit inclusion and significant role of substate and nonstate actors at COP 21 and in the text of the Paris Agreement highlight that "the post-Paris climate regime sees sub/nonstate actors not as an alternative to the UNFCCC process, or as merely a helpful addition, but as a core element of its logic of spurring rising action on climate over time." 65 The politics of the Paris Agreement are therefore evidence of an emerging "hybrid multilateralism" characterized by increased cooperation, interplay, and shared power between state, substate, and nonstate actors. ${ }^{66}$ In increasing the ability of substate and nonstate actors to exercise power and exert influence over other actors, including states, the design and enforcement of the Paris Agreement challenge the existing global order in which states are the primary wielders of power, and provide evidence of a new emerging global order in which states share power with and are balanced by substate and nonstate actors.

\section{Conclusion}

Ultimately, while some aspects of the Agreement's design and ratification reaffirm the existing global order by facilitating cooperation through international institutions via mechanisms of state-exercised soft power, the overall politics of the Paris Agreement provide strong evidence of a new emerging global order. The enforcement of this Agreement reflects this transition by shifting power from state to substate and nonstate actors. While the politics of the Agreement are indicative of a new emerging global order, this new order may still incorporate some elements of the existing one. For example, the Paris Agreement may foster a more integrated world with greater collaboration and cooperation between states, as well as between state and nonstate actors. As illustrated in this paper, the Paris Agreement has already substantially increased the influence of substate and nonstate actors on the international climate regime. Beyond this regime, it is highly likely that these actors will soon play a more integral role in international negotiations and foreign affairs more generally. While it remains uncertain which aspects of the long-standing global order will persist in the newly emerging one, the politics of the Paris Agreement clearly demonstrate a meaningful redistribution of power among the political actors on the international stage, and may therefore significantly shape the future of international relations.

\footnotetext{
${ }^{63}$ Bäckstrand et al., "Non-state actors in global climate governance: from Copenhagen to Paris and beyond," 569.

${ }^{64}$ Hale, "'All Hands on Deck': The Paris Agreement and Nonstate Climate Action," 13.

65 Ibid, 14.

${ }^{66}$ Bäckstrand et al., "Non-state actors in global climate governance: from Copenhagen to Paris and beyond," 562.
} 
Bibliography

Agyeman, Julian, Harriet Bulkeley, and Aditya Nochur. "Climate Justice." In Ignition: What What You Can Do to Fight Global Warming and Spark a Movement, edited by John Isham and S. Waage, 135-44. Washington D.C.: Island Press, 2007.

Bäckstrand, Karin, Jonathan W. Kuyper, Björn-Ola Linnér, and Eva Lövbrand.

"Non-state actors in global climate governance: from Copenhagen to Paris and beyond." Environmental Politics 26, no. 4 (May 26, 2017): 561-79. Accessed January 7 , 2018. doi:10.1080/09644016.2017.1327485.

Bang, Guri, Jon Hovi, and Tora Skodvin. "The Paris Agreement: Short-Term and Long-Term Effectiveness." Politics and Governance 4, no. 3 (2016): 209-18. Accessed October 10, 2017. doi:10.17645/pag,y4i3.640.

Bawden, Tom. "Paris Climate Deal 'Far Too Weak to Prevent Devastating Global Warming." The Independent, January 8, 2016.

http://www.independent.co.uk/environment/climate-change/cop21-paris-deal-far-tooweak-to-prevent-devastating-climate-change-academics-warn-a6803096.html.

Bodansky, Daniel. "The Paris Climate Change Agreement: A New Hope?" The American Journal of International Law 110, no. 2 (2016): 288-319. Accessed October 10, 2017. doi:10.5305/amerjintelaw.110.2.0288.

Climate Vulnerability Monitor: A Guide to the Cold Calculus of a Hot Planet.

Report. 2nd ed. Accessed October 10, 2017. http://daraint.org/wp-content/uploads/2012/09/CVM2-Low.pdf.

Dröge, Susanne. “The Paris Agreement 2015: Turning Point for the International

Climate Regime." Stiftung Wissenschaft und Politik German Institute for International and Security Affairs, February 2016. Accessed October 10, 2017.

http://www.swp-

berlin.org/fileadmin/contents/products/research_papers/2016RP04_dge.pdf.

Falk, Richard. "World Orders, Old and New." Current History 98 (January 1, 1999): 29-34. Accessed January 10, 2018.

https://search-proquest-com.proxy.swarthmore.edu/docview/1309780844?pq-

origsite $=$ gscholar. 
Falkner, Robert. "The Paris Agreement and the new logic of international climate politics." International Affairs 92, no. 5 (September 2016): 1107-125. Accessed October 10, 2017. doi:10.1111/1468-2346.12708.

Gustin, Georgina. "14 States: We're on Track to Meet Paris Climate Goals, Despite Trump." InsideClimate News. September 22, 2017. Accessed January 14, 2018. https://insideclimatenews.org/news/21092017/states-paris-trump-climate-changealliance-leadership-jerry-brown-cuomo-inslee-nrdc-2050.

Hale, Thomas. "'All Hands on Deck': The Paris Agreement and Nonstate Climate Action." Global Environmental Politics 16, no. 3 (August 2016): 12-22. Accessed January 7, 2018. doi:10.1162/glep_a_00362.

Hsu, Angel, Yaping Cheng, Kaiyang Xu, Amy Weinfurter, Cameron Yick, Maria Ivanenko, Subhas Nair, Thomas Hale, Brendan Guy, and Carlin Rosengarten. "Assessing the Wider World of Non-State and Sub-National Climate Action." New Haven: Yale Data Driven Environmental Solutions Group, December 10, 2015. Accessed January 7, 2018. https://campuspress.yale.edu/datadriven/files/2015/12/Assessing-the-Wider-Worldof-Non-state-and-Sub-national-Climate-Action-2d5oghz.pdf.

Jacquet, Jennifer, and Dale Jamieson. "Soft but significant power in the Paris Agreement." Nature Climate Change 6, no. 7 (July 2016): 643-46. Accessed October 10, 2017. doi:10.1038/nclimate3006.

Keck, Margaret E., and Kathryn Sikkink. Activists beyond Borders. Cornell University Press, 1998.

Martini, Catherine. "Transparency: The Backbone of the Paris Agreement." Accessed October 10, 2017. http://envirocenter.yale.edu/transparency-the-backbone-of-the-Paris-Agreement.

Mearsheimer, John J. "Anarchy and the Struggle for Power." In The Tragedy of Great Power Politics, 29-54. New York: W.W. Norton \& Company, 2014. Accessed October 10, 2017.

http://www.ucs.mun.ca/ russellw/Teaching_files/Mearsheimer\%20-\%20Realism.pdf.

"Monterey Bay Aquarium - Inspiring Conservation and Taking Climate Action." We Are Still In. Accessed July 27, 2018. https://www.wearestillin.com/success/monterey-bay-aquarium-inspiring-conservationand-taking-climate-action. 
Nye, Joseph S., Jr. Soft Power: The Means to Success in World Politics. New York: PublicAffairs, 2005.

Nye, Joseph S., Jr. "Will the Liberal Order Survive?” Foreign Affairs 96, no. 1 (Jan. \& Feb. 2017). Accessed January 7, 2018. https://www.foreignaffairs.com/articles/2016-12-12/will-liberal-order-survive.

Page, Samantha. 'No, The Paris Climate Agreement Isn't Binding. Here's Why That Doesn't Matter." Accessed October 10, 2017. https://thinkprogress.org/no-the-paris-climateagreement-isnt-binding-here-s-why-that-doesn-t-matter-62827c72bb04/.

"Paris Agreement." UNFCCC. Accessed July 26, 2018. https://unfccc.int/files/meetings/paris_nov_2015/application/pdf/paris_agreement_english -.pdf.

"Paris Agreement Ratification Tracker." Climate Analytics. Accessed January 14, 2018.

http://climateanalytics.org/briefings/ratification-tracker.html.

“Signify Aims to be Carbon Neutral by 2020." We Are Still In. Accessed July 27, 2018.

https://www.wearestillin.com/success/signify-aims-be-carbon-neutral-2020.

Smith-Spark, Laura. "EU, China unite behind Paris climate deal despite Trump withdrawal." CNN. June 01, 2017. Accessed January 7, 2018. http://www.cnn.com/2017/06/01/europe/eu-us-climate/index.html.

“The Paris Agreement - Status of Ratification.” UNFCCC. Accessed July 26, 2018. https://unfccc.int/process/the-paris-agreement/status-of-ratification.

Towns, Ann E., and Bahar Rumelili. "Taking the Pressure: Unpacking the Relation between Norms, Social Hierarchies, and Social Pressures on States." European Journal of International Relations 23, no. 4 (2017): 756-79. Accessed April 25, 2018. doi:10.1177/1354066116682070.

U.S. Climate Alliance Annual Report: Alliance States Take the Lead. Report. 2017.

Accessed January 14, 2018.

https://tinyurl.com/y87467rc.

Van Asselt, Harro. "The Role of Non-State Actors in Reviewing Ambition, Implementation, and Compliance Under the Paris Agreement." Climate Law 6, no. 1 (2016): 91-108. Accessed January 7, 2018. doi:10.1163/18786561-00601006. 
Viotti, Paul R., and Mark V. Kauppi. International Relations and World Politics. 5th ed. New York, NY: Pearson, 2013.

Walt, Stephen M. "International Relations: One World, Many Theories." Foreign Policy, no. 110 (1998): 29-46. doi:10.2307/1149275.

Waltz, Kenneth Neal. "The Anarchic Structure of World Politics." In Theory of International Politics, 79-106. McGraw Hill, 1979. Accessed October 10, 2017. http://www.drmalikcikk.atw.hu/wp_readings/waltz.pdf.

Yeo, Sophie. "Timeline: The Paris Agreement's 'Ratchet Mechanism."” Carbon Brief, January 19, 2016.

https://www.carbonbrief.org/timeline-the-paris-agreements-ratchet-mechanism. 